\title{
Mass-spectrometric and bioinformatic analysis of eEF1B $\gamma$ interactome in the cytoplasmic fraction of A549 cells
}

\author{
L. M. Kapustian, I. L. Lysetsky, T. V. Bondarchuk, O. V. Novosylna, B. S. Negrutskii \\ Institute of Molecular Biology and Genetics, NAS of Ukraine \\ 150, Akademika Zabolotnoho Str., Kyiv, Ukraine, 03143 \\ negrutskii@imbg.org.ua
}

\begin{abstract}
Aim. To study protein networks containing the translation elongation factor eEF1B gamma (eEF1B $\gamma$ ) in lung carcinoma cells. Methods. The protein partners of eEF1B $\gamma$ in the cytoplasmic fraction of human lung adenocarcinoma A549 cells were identified by co-immunoprecipitation (co-IP) followed by subsequent liquid chromatography-tandem mass spectrometry (LC-MS/MS). The protein interaction network for eEF1B $\gamma$ was determined by a Cytoscape 3.2.0 program using a MCODE plugin. Results. 222 high-scored proteins interacting with eEF1B $\gamma$ in the cytoplasm of A549 cells have been identified. Possible functional networks involving these protein-protein interactions were predicted using bioinformatic approaches. Conclusions. Five protein networks were identified as possible targets of eEF1B $\gamma$ in lung cancer cells. Apart from translation, eEF1B $\gamma$ was shown to be potentially involved in cell cycle regulation, nucleosome remodeling, transcription, mRNA splicing and processing, and oxidative stress response.
\end{abstract}

Ke y w o r d s: eEF1B $\gamma$, protein-protein interactions, A549 cells

\section{Introduction}

eEF1Bg is a non-catalytic subunit of the eEF1B complex responsible for GDP/GTP exchange in translation elongation factor eEF1A. Apart from eEF1Bg, eEF1B contains two catalytic subunits, eEF1B $\alpha$ and eEF1B $\beta$. Altogether eEF1A and the eEF1B complex provide efficient and accurate translation of mRNA on ribosomes in cytoplasm of eukaryotic cells. However, the data on the existence of a free pool of the eEF1B subunits in human cancer tissues [1.2] suggested their non-translational functioning as well. The nature of these non-canonical functions remains mostly unidentified.

Recently, the information on cellular processes that can engage the oncogenic eEF1B $\beta$ subunit in cancer cells has been obtained $[3,4]$. While a direct information about an oncogenic role of the eEF1Bg subunit is absent, there are several reports on its overexpression in cancer cells [5-8]. This suggests a possibility of cancer-related functioning of this pro-

(C) 2018 L. M. Kapustian et al.; Published by the Institute of Molecular Biology and Genetics, NAS of Ukraine on behalf of Biopolymers and Cell. This is an Open Access article distributed under the terms of the Creative Commons Attribution License (http://creativecommons.org/licenses/by/4.0/), which permits unrestricted reuse, distribution, and reproduction in any medium, provided the original work is properly cited 
tein. Here, we used the combination of coimmunoprecipitation, mass-spectrometry and bioinformatics to investigate a cytoplasmic interactome of the eEF1Bg protein in human cancer cells. In particular, we aimed to shed light on non-translational cancer-related processes which can involve eEF1Bg in lung cancer.

The obtained results show that eEF1B $\gamma$ may be involved in cell cycle regulation, nucleosome remodeling, mRNA splicing and processing, viral mRNA transcription and oxidative stress response in lung cancer cells.

\section{Materials and Methods}

\section{Preparation of cytoplasmic fraction of human lung cells}

Human lung cancer cells A-549 were harvested with Trypsin-EDTA. Cytoplasmic fraction was isolated as in [3]. Briefly, the cells were lysed with 1.5 volume of buffer containing $10 \mathrm{mM}$ HEPES pH7.9, $1.5 \mathrm{mM}$ $\mathrm{MgCl}_{2}, 0.5 \%$ NP-40, $0.2 \mathrm{mM}$ PMSF, $0.5 \mathrm{mM}$ DTT and kept on ice for $20 \mathrm{~min}$. Then, the cells were centrifuged $10 \mathrm{~min}$ at $400 \mathrm{~g}$. The supernatant was subjected to centrifugation at $16000 \mathrm{~g}$ for $30 \mathrm{~min}$. The obtained supernatant was used as cytoplasmic extract. The absence of nuclear fraction admixture was verified by Western blotting with antiPoly(ADP-ribose) polymerase and anti-Histone 3.3 antibodies.

\section{Co-immunoprecipitation}

The cytoplasmic extract was pre-cleared with Protein G Sepharose (Sigma, USA) for $1 \mathrm{~h}$ at $4{ }^{\circ} \mathrm{C}$. Anti-eEF1B $\gamma$ antibodies (Abnova, Taiwan) $(1.5 \mu \mathrm{g}$ of antibodies per $1 \mathrm{mg}$ of total protein) were added to pre-cleared lysates and incubated overnight at $4{ }^{\circ} \mathrm{C}$. After addition of Protein G Sepharose slurry the incubation persisted for $2 \mathrm{~h}$ at $4{ }^{\circ} \mathrm{C}$ with continuous shaking. Then the resin was washed with ten resin volumes of the lysis buffer and treated further in accordance with the manufacturer's protocol. After elution of eEF1B $\gamma$-associated proteins, the $12 \%$ PAGE was performed [9]. The protein bands of interest were cut and processed for mass-spectrometry analysis (LC-MS/MS).

\section{Mass-spectrometry LC-MS/MS}

The cytoplasmic extract incubated with plain G-Sepharose was used as a control of nonspecific binding. The electrophoretic bands that were not present in the control or were much more extensive than in the control were cut and processed for mass spectrometry analysis at the Mass Spectrometry Laboratory of the Institute of Biochemistry and Biophysics (Warsaw, Poland) using LTQ-Orbitrap Velos mass spectrometer (Thermo Scientific) equipped with nanoAcquity (Waters Corporation) LC system, with ions score or expect cut-off, 30 and significance threshold, $\mathrm{p}<0.05$, as described before $[3,4]$.

\section{Bioinformatics analysis}

Cytoscape 3.2.0 Program [10] interaction database BIOGRID was supplemented with newly identified protein partners of eEF1B $\gamma$ and analyzed by MCODE plugin which finds highly interconnected regions (clusters) in any network loaded into Cytoscape. These clusters have been shown to represent protein complexes and/or parts of pathways [11]. For the sake of clarity, such known protein partners of 
eEF1B $\gamma$ as eEF1A1, eEF1A2 and UBC (polyubiquitin-C) were excluded from the database as they interact with a huge number of cell proteins and create a very complicated network of protein-protein interactions that is not associated with eEF1B $\gamma$ directly [3]. Also, we simplified the task by taking for analysis only the first (direct) partners of eEF1B $\gamma$ partners determined by the Program algorithm. MCODE analysis was performed on the hybrid supercomputer "SCIT-4" at the Glushkov Institute of Cybernetics (GIC) of National Academy of Sciences of Ukraine (http://icybcluster.org.ua).

\section{Results and Discussion}

Literature data indicate that $\mathrm{eEF} 1 \mathrm{Bg}$ may have connections with different types of cytoskeleton $[12,13]$ and interact with viral components $[14,15]$, it may be involved in transcription process [16-18] and oxidative stress response [19].
Our study was aimed to examine whether these and other cellular processes implicate eEF1B $\gamma$ in lung cancer cells. We identified 222 proteins as the interacting partners of eEF1B $\gamma$ in the cytoplasm of human lung adenocarcinoma A549 cells by using co-immunoprecipitation and subsequent LC-MS/MS identification of the interacting proteins. These protein partners were used for further analysis by the Cytoscape program to predict functional clusters, which may involve these proteins.

First, human BioGRID database was employed to generate by the MCODE the protein interaction network of eEF1B $\gamma$ based on existing (published) data. The resulting network contained 11 proteins (including eEF1B $\gamma$ ). Three of them showed direct interactions with eEF1B $\gamma$ (Fig. 1). Those are eEF1B $\beta$ (Gene ID 1936), FLNC (filamin C, gamma, Gene ID 2318) and NUDT21 (Cleavage and polyadenylation specificity factor subunit 5 , Gene

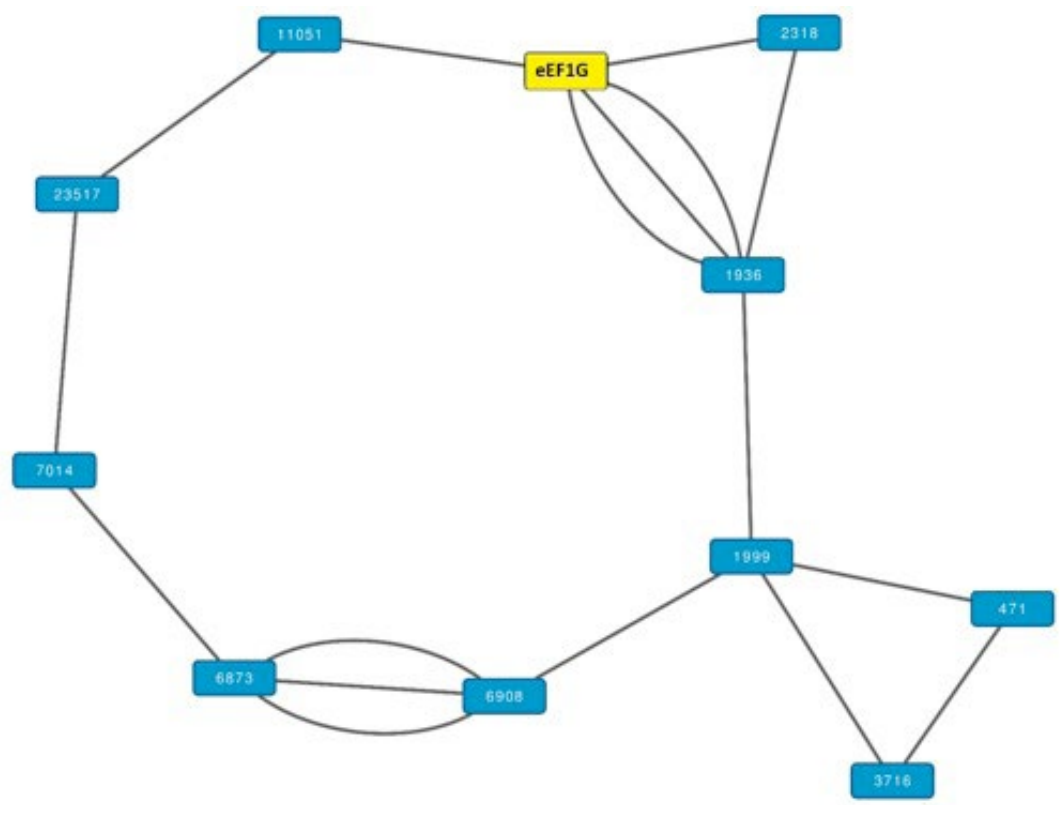

Fig. 1. Protein cluster containing eEF1B $\gamma$, generated by MCODE in the Cytoscape 3.2.0 Program from Human BioGRID database solely on the basis of literature data. 
ID 11051). The other members of this protein network are: SKIV2L2 (Ski2 Like RNA Helicase 2, Gene ID 23517), TERF1 (Telomeric repeat-binding factor 1 , Gene ID 7014), TAF2 (TATA-box binding protein associated factor 2, Gene ID 6873), TBP (TATA-box binding protein, Gene ID 6908), ELF3 (ETS-related transcription factor Elf-3, Gene ID 1999), JAK1 (Janus kinase 1, Gene ID 3716) and ATIC (5-aminoimidazole-4-carboxamide ribonucleotide formyltransferase/IMP cyclohydrolase, Gene ID 471). The majority of these proteins participate in synthesis and degradation of mRNA and its regulation (20-24).

Second, a protein network was generated by MCODE after complementing the BioGrid database with newly identified 222 partners of eEF1B $\gamma$. Resulting protein cluster contained 55 proteins (including eEF1B $\gamma$ ) (Fig. 2). Several functional protein sub-clusters were identified among the main cluster. Subcluster $A$ included the proteins associated with mRNA splicing and processing. Sub-cluster $B$ contained the proteins participating in nucleosome remodeling via changes of post-translational modifications of histones and DNA binding. The proteins from sub-cluster $C$ were involved in cell cycle events. Sub-cluster D mostly comprised the members of translation apparatus, and sub-cluster $E$ contained the transcription factors associated with oxidative stress response. The detailed analysis of the

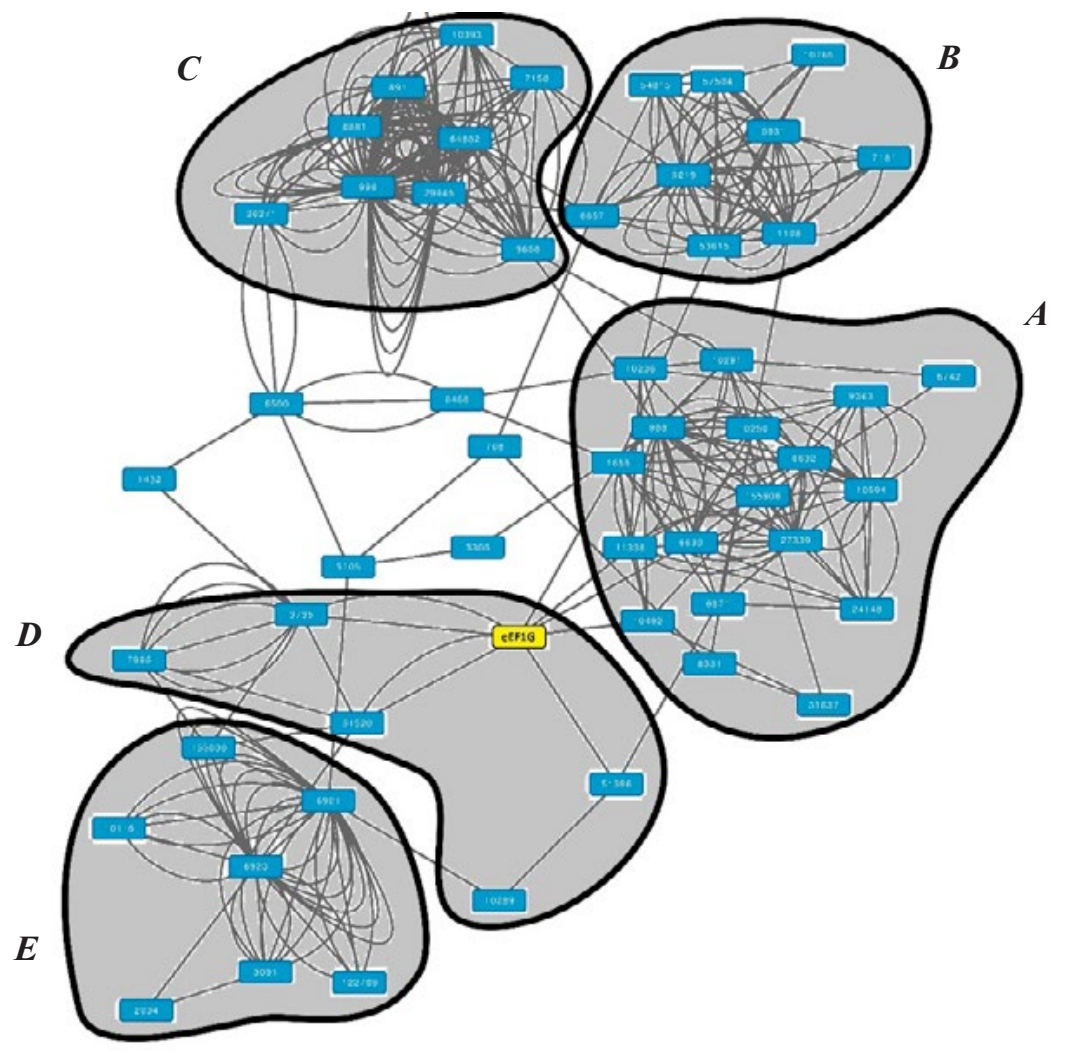

Fig. 2. Protein cluster containing eEF1B $\gamma$, generated by MCODE in the Cytoscape 3.2.0 Program from Human BioGRID database supplemented with co-IP/MS-MS experimental data. Sub-clusters: $A-$ the proteins associated with mRNA splicing and processing, $B$ - nucleosome remodeling which proceeds via changes in the post-translational modifications of histones, $C-$ the proteins involved in cell cycle events, $D-$ translation and viral RNA replication, $E$ - oxidative stress response. 
protein components of the sub-clusters is shown below.

Sub-cluster A contained 3 experimentally identified in this paper protein partners of eEF1B $\gamma$ - DDX5 (Probable ATP-dependent RNA helicase DDX5, Gene ID 1655), SYNCRIP (Heterogeneous nuclear ribonucleoprotein Q, Gene ID 10492) and U2AF2 (Splicing factor U2AF $65 \mathrm{kDa}$ subunit, Gene ID 11338). The proteins CDC5L (Cell division cycle 5-like, Gene ID 988), SRRM1 (Serine/arginine repetitive matrix 1, Gene ID 10250), SNRPD1 (Small nuclear ribonucleoproteinD1polypeptide $16 \mathrm{RDa}$, Gene ID 6632), PRPF19 (Pre-mRNA processing factor 19, Gene ID 27339), rev P19 (Protein Rev p19, Gene ID 155908) and SNPD2 (Small nuclear ribonucleoprotein D2 polypeptide $16.5 \mathrm{kDa}$, Gene ID 6633) formed the central core of sub-cluster $A$. The outer layer of this group contained the proteins HNRNPR (Heterogeneous nuclear ribonucleoprotein $\mathrm{R}$, Gene ID 10236), SF3A (Splicing factor 3A, subunit 1, Gene ID 10291), EFTUD2 (Elongation factor Tu GTP binding domain containing 2, Gene ID 9343), SSBP1 (Single stranded DNA binding protein 1 , Gene ID 6742), PRPF8 (Pre-mRNA processing factor 8, Gene ID 10594), PRPF6 (Pre-mRNA processing factor 6 , Gene ID 24148), YBX3 (Y box binding protein 3, Gene ID 8531), TADA2A (Transcriptional adaptor 2A, Gene ID 6871), SYNCRIP (Heterogeneous nuclear ribonucleoprotein Q, Gene ID 10492), U2AF2 (U2 small nuclear RNA auxiliary factor 2, Gene ID 11338), DDX5 (Probable ATPdependent RNA helicase DDX5, Gene ID 1655), and C14orf166 (Chromosome 14 Open Reading Frame 166, Gene ID 51637).
Association of eEF1B $\gamma$ with sub-cluster $A$ suggests its participation in the mRNA splicing and processing events. Peculiarly, the splicing complexes are normally localized in the nucleus, whereas the interaction of eEF1B $\gamma$ with the members of sub-cluster $A$ is observed in the cytoplasmic fraction of the cells. One of the possible explanation is that eEF1B $\gamma$ participates in cyto-nuclear transport of the components of the sub-cluster A. As indicated in the Materials and Methods section, the absence of admixture of the nuclear proteins in the cytoplasmic fraction was routinely controlled by Western blotting with anti-Poly(ADP-ribose) polymerase and anti-Histone 3.3 antibodies. This significantly diminishes the possibility of artefact presence of the components of the splicing machinery in cytoplasm.

According to bioinformatics analysis, $s u b$ cluster $B$ is linked to sub-cluster $A$ via several proteins: CHD4 (Chromodomain helicase DNA binding protein 4, Gene ID 1108), MTA2 (Metastasis associated 1 family, member 2, Gene ID 9219) and MBD3 (Methyl-ChG binding domain protein 3, Gene ID 53615). There are six more proteins in this sub-cluster: NR2C1 (Nuclear receptor subfamily 2, group C, member 1, Gene ID 7181), RBBP7 (Retinoblastoma Binding Protein 7, Gene ID 5931), KDM5B (Lysine-specific demethylase 5B, Gene ID 10765), MTA3 (metastasis associated 1 family, member 3, Gene ID 57504), GATAD2A (GATA zinc finger domain containing 2A, Gene ID 54815), and SOX2 (SRY (Sex determining region Y)-box 2 , Gene ID 6657). The main function of subcluster $B$ is suggested to be a nucleosome remodeling which proceeds via changes in the post-translational modifications of histones. 
Thus, eEF1B $\gamma$ can be possibly involved in controlling the pre-translational gene expression events.

The proteins SOX2 and MTA3 functionally link sub-clusters $B$ and $C$. The core of sub-cluster $C$ contains five proteins: CCNB1 (cyclin B1, Gene ID 891), CDC16 (Cell Division Cycle 16, Gene ID 8881), ANAPC1 (Anaphase Promoting Complex Subunit 1, Gene ID 64682), ANAPC4 (Anaphase Promoting Complex Subunit 4, Gene ID 29945), and CDC27 (Cell Division Cycle 27, Gene ID 996). All these proteins, except cyclin B1, are the components of the Anaphase Promoting Complex (APC), which maintains the metaphase-anaphase transition due to the degradation of cyclin B1. Cyclin $\mathrm{B} 1$ is associated with $\mathrm{G} 2 / \mathrm{M}$ transition of mitotic cell cycle. Other two proteins of $s u b$ cluster $C$ are TP53BP1 (Tumor Protein P53 Binding Protein 1, Gene ID 7158) and MDC1 (Mediator of DNA-Damage Checkpoint 1, Gene ID 9656). The last one is connected with sub-cluster $A$ by two links. Importantly, possible association of eEF1B $\gamma$ with the cell cycle regulation components has been reported [25].

The protein FBXO5 (F- box protein 5, Gene ID 26271), which can inhibit APC complex due to its ubiquitin ligase activity, connects sub-cluster $C$ with sub-clusters $A$ and $D$ through SKP1 (S-phase kinase-associated protein 1, Gene ID 6500). The SKP1 protein takes part in ubiquitination of FBXW4 (F-Box and WD Repeat Domain Containing 4, Gene ID 6468), which in turn interacts with two proteins of sub-cluster A, one of them (DDX5) was experimentally identified as a partner of $\mathrm{eEF} 1 \mathrm{~B} \gamma$ in this paper.
The protein MAPK14 (mitogen-activated protein kinase 14, Gene ID1432) links subclusters $C$ and $D$. This kinase belongs to the family of MAP-kinases, which integrate ubiquitous cellular signals and participate in regulation of transcription, differentiation, proliferation and cell development. MAPK14 is implicated in the control of the genotoxic stress response and in the stress-induced transcription and cell cycle regulation [26]. According to the scheme, in sub-cluster D this protein interacts with SKP1 (S-Phase KinaseAssociated Protein1, Gene ID 6500), which participates in regulation of ubiquitination, and KARS (lysyl-tRNA synthetase, Gene ID 3735). KARS is associated with protein biosynthesis and also interacts with gag Pr55 (Gag polyprotein (Human immunodeficiency virus 1), Gene ID 155030). KARS interaction with gag Pr55 assists effective packaging of $\mathrm{tRNA}_{3}{ }^{\text {Lys }}$, which works as a primer for initiation of the reverse transcription, to viral particles [27]. The protein AIMP2 (Aminoacyl tRNA Synthetase Complex-Interacting Multifunctional Protein 2, Gene ID 7965) from sub-cluster $D$ interacts with KARS and LARS (Leucyl-TRNA Synthetase, Gene ID 51520) in the macromolecular aminoacyl-tRNA synthetase complex. Interestingly, another component of HIV-1 virus, the protein rev p19, is also found in the interactome of eEF1B $\gamma(s u b-$ cluster $A$ ). Thus, on the non-translational side, the data on sub-clusters $D$ and $A$ provide independent support to the notion that eEF1B $\gamma$ can take part in functioning of HIV-1 virus [14]. In particular, it may play a role of structural platform for spatial immobilization of some viral and host-cell proteins leading to more effective viral replication. 
The protein PCK1 (Phosphoenolpyruvate Carboxykinase 1, Gene ID 5105) connects sub-clusters $A, B, C$, and $E$. This protein is at the main checkpoint in control of gluconeogenesis. PCK1 is linked to sub-cluster $A$ via the protein HSPA1L (Heat Shock $70 \mathrm{kDa}$ Protein 1-Like, Gene ID 5105). PCK1 is connected to sub-claster $B$ through the protein C1QBP (Complement Component 1, Q Subcomponent Binding Protein, Gene ID 708), a multifunctional protein, associated with inflammation and infection processes, apoptosis, transcription and pre-mRNA splicing regulation, and ribosome biogenesis [28]. C1QBP interacts with the protein SOX2 from $s u b$ cluster $B$ that links sub-clusters $C$ and $B$. It also interacts with the protein YBX3 (Y Box Binding Protein 3, Gene ID 8531) from subcluster $A$, which can act as a transcription factor specifically binding certain DNA sequences, in particular ds-DNA. PCK1 is linked to sub-cluster $E$ through interaction with the proteins ELOC (Elongin-C, Gene ID 6921) and ELOB (Elongin-B, Gene ID 6923). ELOC and ELOB are the regulatory subunits of the transcription factor B (SIII) complex, which activates RNA-polymerase II-mediated transcription elongation. Interestingly, eEF1B $\gamma$ was reported to interact with RNA-polymerase II [16].

Sub-cluster $E$ also includes LRR1 (Leucinerich repeat protein 1, Gene ID 122769), a negative regulator of 4-1BB-mediated signaling, which leads to the NK-kappaB and JNK1 activation [29]. An independent study showed that $\mathrm{eEF} 1 \mathrm{~B} \gamma$ is a positive regulator of NFкарраB signaling pathway, with unknown mechanism of action [17]. Another component of this sub-cluster $E$ is HIF1A (Hypoxia
Inducible Factor 1, Alpha Subunit (Basic Helix-Loop-Helix Transcription Factor, Gene ID 3091), a subunit of transcription factors complex HIF-1, which is a main regulator of anti-hypoxic homeostatic cell response. This factor is responsible for the transcription activation of many genes involved in energetic metabolism, angiogenesis, apoptosis as well as of the genes that product an enhanced oxygen transition or raise anti-hypoxic metabolic adaptation level [30]. The protein EPAS1 (Endothelial PAS Domain Protein 1, Gene ID 2034) is a link between HIF1A and ELOB. This protein is a transcription factor associated with induction of the genes regulated by oxygen. The protein FEM1B (Fem-1 Homolog B, Gene ID 10116) belongs to a family of death receptor-associated proteins essential for apoptosis. Thus, sub-cluster $E$ mainly contains the transcription factors participating in the induction of the oxidative stress response, which can play adaptive or apoptotic role.

Several papers suggested possible participation of eEF1B $\gamma$ in oxidative stress response $[19,31,32]$, however the details of such connection were not presented. Our data predict existence of the direct links between eEF1B $\gamma$ and transcription factors involved in induction of this response. This connection can be used as a new target for drugs with a capacity of jugulating oxidative stress response in human cells.

Translation initiation factor eIF1B (subcluster $D$ ) interacts with transcription factor ELOC (sub-cluster E) and with translation initiation factor eIF3L (Eukaryotic Translation Initiation Factor 3, Subunit L, Gene ID 51386). Factor eIF3L interacts with eEF1B $\gamma$ closing 
the loop of interactions in sub-cluster D. On the other hand, eIF3L interacts with TADA2A (sub-cluster A) which is a member of the histone-acetylase complex PCAF. It is one more link that connects eEF1B $\gamma$ with sub-cluster $A$, the function of which is associated with the nucleosome structure modification.

Several identified protein partners of eEF1B $\gamma$ are associated with human diseases. The proteins CCNB1 and FBXO5 from subcluster $C$ are associated with tetraploidy [33]. The proteins CCNB1, MDC1 and MTA3 (subcluster $C$ ) are linked to breast cancer [34-36]. The protein PRPF8 (sub-cluster A) is related to myeloid neoplasms [37]. The proteins CDC5L and PRPF19 from sub-cluster A participate in the development of poikiloderma with neutropenia [38]. The proteins CDC27 (sub-cluster C) and SSBP1 (sub-cluster A) are associated with herpes infection $[39,40]$. The proteins MAPK14 (sub-cluster D) and HIF1A (sub-cluster $E$ ) are involved in vascular disease $[41,42]$. DDX5 (sub-cluster A) participates in the necrosis development [43].

Surprisingly, seven proteins from sub-clusters $A, B, C$ and protein PCK1, which connects these sub-clusters, are involved in corneal diseases, particularly retinoblastoma. It opens an interesting possibility of the eEF1B $\gamma$ involvement in the development of human corneal diseases.

As eEF1B $\gamma$ has no evident catalytic activity, we suggest that the potential molecular mechanisms of its participation in non-translational events could involve its ability to form multimeric structures. In such way, eEF1B $\gamma$ can serve as a scaffold for various protein partners participating in a variety of cellular processes.

\section{Conclusions}

222 proteins were identified by co-immunoprecipitation, with subsequent LC-MS-MS, as interacting with eEF1B $\gamma$ in the cytoplasm of human lung adenocarcinoma A549 cells. The eEF1B $\gamma$ protein partners were used to construct possible functional networks by the Cytoscape 3.2.0 program. We identified five protein networks (sub-clusters), which can involve eEF1B $\gamma$ in human cancer cells. They are linked to mRNA splicing and processing; nucleosome remodeling; cell cycle regulation; viral RNA transcription; oxidative stress response. Thus, our data support and detail the previously reported cases of eEF1B $\gamma$ linkage to the processes of cell cycle, transcription of viral RNAs and oxidative stress response. Moreover, they indicate, for the first time, a possible participation of eEF1B $\gamma$ in the mRNA maturation and nucleosome remodeling in human cancer cells.

\section{Acknowledgments}

This work was partially financed by the Interdisciplinary Program of Scientific research of NAS of Ukraine "Molecular and cell biotechnologies for medicine, industry and agriculture" and Collaborative Program of NAS of Ukraine and PAN 2018-2020. The financing by Ministry of Science and Education of Ukraine and Ministry of Science and High Education of Poland is appreciated. We thank Prof. M. Dadlez for an expert help in performing MS analysis. We appreciate the contribution of V. Zakon and Dr. I. Groisman to the categorization of MS data. We are grateful to M. M. Ilchenko for valuable advices. 


\section{REFERENCES}

1. Veremieva $M$, Khoruzhenko A, Zaicev $S$, Negrutskii B, El'skaya A. Unbalanced expression of the translation complex eEF1 subunits in human cardioesophageal carcinoma. Eur J Clin Invest. 2011;41(3):269-76.

2. Veremieva $M$, Kapustian L, Khoruzhenko $A$, Zakharychev V, Negrutskii B, El'skaya A. Independent overexpression of the subunits of translation elongation factor complex eEF1H in human lung cancer. BMC Cancer. 2014;14:913.

3. Kapustian LM, Dadlez M, Negrutskii BS. Non-canonical interactions of the $\beta$ subunit of the translation elongation complex eEF1B and analysis of their possible functional role. Biopolym Cell. 2016; 32(5):347-58.

4. Kapustian LM, Dadlez M, Negrutskii BS. Protein partners of the eEF1B $\beta$ subunit of the translation elongation complex eEF1B in the nuclear fraction of human lung carcinoma cells. Biopolym. Cell. 2017; 33(4):243-55.

5. Shuda M, Kondoh N, Tanaka K, Ryo A, Wakatsuki T, Hada A, Goseki N, Igari T, Hatsuse K, Aihara T, Horiuchi S, Shichita M, Yamamoto N, Yamamoto M. Enhanced expression of translation factor mRNAs in hepatocellular carcinoma. Anticancer Res. 2000;20(4):2489-94.

6. Lew Y, Jones DV, Mars WM, Evans D, Byrd D, Frazier ML. Expression of elongation factor-1 gamma-related sequence in human pancreatic cancer. Pancreas. 1992;7(2):144-52.

7. Mimori K, Mori M, Tanaka S, Akiyoshi T, Sugimachi $K$. The overexpression of elongation factor 1 gamma mRNA in gastric carcinoma. Cancer. 1995;75(6 Suppl):1446-9.

8. Chi K, Jones DV, Frazier ML. Expression of an elongation factor 1 gamma-related sequence in adenocarcinomas of the colon. Gastroenterology. 1992;103(1):98-102.

9. Kang $D-H$, Gho $Y-S$, Suh $M-K$, Kang $C-H$. Highly sensitive and fast protein detection with coomassie brilliant blue in sodium dodecyl sulfate-polyacrylamide gel electrophoresis. Bull Korean Chem Soc. 2002; 23(11):1511-12.
10. Shannon P, Markiel A, Ozier O, Baliga NS, Wang JT, Ramage D, Amin N, Schwikowski B, Ideker T. Cytoscape: a software environment for integrated models of biomolecular interaction networks. Genome Res. 2003;13(11):2498-504.

11. Bader GD, Hogue $C W$. An automated method for finding molecular complexes in large protein interaction networks. BMC Bioinformatics. 2003;4:2.

12. Serpinskaya AS, Tuphile K, Rabinow L, Gelfand VI. Protein kinase Darkener of apricot and its substrate EF $1 \gamma$ regulate organelle transport along microtubules. J Cell Sci. 2014;127(Pt 1):33-9.

13. Kim S, Kellner J, Lee CH, Coulombe PA. Interaction between the keratin cytoskeleton and eEF1Bgamma affects protein synthesis in epithelial cells. Nat Struct Mol Biol. 2007;14(10):982-3.

14. Warren K, Wei T, Li D, Qin F, Warrilow D, Lin MH, Sivakumaran H, Apolloni A, Abbott CM, Jones A, Anderson JL, Harrich D. Eukaryotic elongation factor 1 complex subunits are critical HIV-1 reverse transcription cofactors. Proc Natl Acad Sci U S A. 2012;109(24):9587-92.

15. Zhang Z, Pan L, Ding Y, Lv J, Zhou P, Fang Y, Liu X, Zhang $Y$, Wang $Y$. eEF1G interaction with foot-andmouth disease virus nonstructural protein 2B: Identification by yeast two-hybrid system. Microb Pathog. 2017;112:111-116.

16. Corbi N, Batassa EM, Pisani C, Onori A, Di Certo MG, Strimpakos G, Fanciulli M, Mattei E, Passananti $C$. The eEF1 $\gamma$ subunit contacts RNA polymerase II and binds vimentin promoter region. PLoS One. 2010;5(12):e14481.

17. Liu D, Sheng C, Gao S, Jiang W, Li J, Yao C, Chen $H, W u J$, Chen $S$, Huang $W$. eEF1B $\gamma$ is a positive regulator of NF-кB signaling pathway. Biochem Biophys Res Commun. 2014;446(2):523-8.

18. Pisani C, Onori A, Gabanella F, Delle Monache F, Borreca A, Ammassari-Teule M, Fanciulli M, Grazia Di Certo M, Passananti C, Corbi N. eEF1B $\gamma$ binds the Che-1 and TP53 gene promoters and their transcripts. J Exp Clin Cancer Res. 2016; 35(1):146.

19. Olarewaju O, Ortiz PA, Chowdhury WQ, Chatterjee I, Kinzy $T G$. The translation elongation factor eEF1B plays a role in the oxidative stress response pathway. RNA Biol. 2004;1(2):89-94. 
20. Brumbaugh J, Di Stefano B, Wang X, Borkent $M$, Forouzmand E, Clowers KJ, Ji F, Schwarz BA, Kalocsay M, Elledge SJ, Chen Y, Sadreyev RI, Gygi SP, Hu G, Shi Y, Hochedlinger K. Nudt21 Controls Cell Fate by Connecting Alternative Polyadenylation to Chromatin Signaling. Cell. 2018;172(1-2):106-120.e21.

21. Fan J, Kuai B, Wu G, Wu X, Chi B, Wang L, Wang K, Shi Z, Zhang H, Chen S, He Z, Wang S, Zhou Z, $L i G$, Cheng $H$. Exosome cofactor hMTR4 competes with export adaptor ALYREF to ensure balanced nuclear RNA pools for degradation and export. EMBO J. 2017;36(19):2870-2886.

22. Feigerle JT, Weil PA. The C Terminus of the RNA Polymerase II Transcription Factor IID (TFIID) Subunit Taf2 Mediates Stable Association of Subunit Taf14 into the Yeast TFIID Complex. J Biol Chem. 2016;291(43):22721-22740.

23. Teves SS, An L, Bhargava-Shah A, Xie L, Darzacq X, Tjian $R$. A stable mode of bookmarking by TBP recruits RNA polymerase II to mitotic chromosomes. Elife. 2018;7. pii: e35621.

24. Hubbard SR. Mechanistic Insights into Regulation of JAK2 Tyrosine Kinase. Front Endocrinol (Lausanne). 2018;8:361.

25. Yu L, Peña Castillo L, Mnaimneh S, Hughes TR, Brown GW. A survey of essential gene function in the yeast cell division cycle. Mol Biol Cell. 2006;17(11):4736-47.

26. Bulavin DV, Higashimoto Y, Popoff IJ, Gaarde WA, Basrur V, Potapova O, Appella E, Fornace AJ Jr. Initiation of a $\mathrm{G} 2 / \mathrm{M}$ checkpoint after ultraviolet radiation requires p38 kinase. Nature. 2001;411(6833):102-7.

27. Kleiman L, Jones CP, Musier-Forsyth K. Formation of the tRNALys packaging complex in HIV-1. FEBS Lett. 2010;584(2):359-65.

28. McGee AM, Douglas DL, Liang Y, Hyder SM, Baines $C P$. The mitochondrial protein $\mathrm{Clqbp}$ promotes cell proliferation, migration and resistance to cell death. Cell Cycle. 2011;10(23):4119-27.

29. Jang LK, Lee ZH, Kim HH, Hill JM, Kim JD, Kwon BS. A novel leucine-rich repeat protein (LRR-1): potential involvement in 4-1BB-mediated signal transduction. Mol Cells. 2001;12(3):304-12.
30. Ziello JE, Jovin IS, Huang Y. Hypoxia-Inducible Factor (HIF)-1 regulatory pathway and its potential for therapeutic intervention in malignancy and ischemia. Yale J Biol Med. 2007;80(2):51-60.

31. Esposito AM, Kinzy TG. The eukaryotic translation elongation Factor 1Bgamma has a non-guanine nucleotide exchange factor role in protein metabolism. J Biol Chem. 2010;285(49):37995-8004.

32. O'Keeffe G, Jöchl C, Kavanagh K, Doyle S. Extensive proteomic remodeling is induced by eukaryotic translation elongation factor 1B $\gamma$ deletion in Aspergillus fumigatus. Protein Sci. 2013;22(11):1612-22.

33. Lehman NL, Verschuren EW, Hsu JY, Cherry AM, Jackson PK. Overexpression of the anaphase promoting complex/cyclosome inhibitor Emil leads to tetraploidy and genomic instability of p53-deficient cells. Cell Cycle. 2006;5(14):1569-73.

34. Ding K, Li W, Zou Z, Zou X, Wang C. CCNB1 is a prognostic biomarker for ER+ breast cancer. Med Hypotheses. 2014;83(3):359-64.

35. Zou R, Zhong $X$, Wang $C$, Sun $H$, Wang $S$, Lin L, Sun S, Tong C, Luo H, Gao P, Li Y, Zhou T, Li D, Cao L, Zhao Y. MDC1 Enhances Estrogen Receptormediated Transactivation and Contributes to Breast Cancer Suppression. Int J Biol Sci. 2015;11(9):9921005.

36. Zhang H, Stephens LC, Kumar R. Metastasis tumor antigen family proteins during breast cancer progression and metastasis in a reliable mouse model for human breast cancer. Clin Cancer Res. 2006;12(5):1479-86.

37. Kurtovic-Kozaric A, Przychodzen B, Singh J, Konarska MM, Clemente MJ, Otrock ZK, Nakashima $M$, Hsi ED, Yoshida K, Shiraishi Y, Chiba K, Tanaka H, Miyano S, Ogawa S, Boultwood J, Makishima H, Maciejewski JP, Padgett RA. PRPF8 defects cause missplicing in myeloid malignancies. Leukemia. 2015;29(1):126-36.

38. Shchepachev V, Wischnewski H, Missiaglia E, Soneson C, Azzalin CM. Mpn1, mutated in poikiloderma with neutropenia protein 1 , is a conserved 3'-to-5' RNA exonuclease processing U6 small nuclear RNA. Cell Rep. 2012;2(4):855-65.

39. Sun Z, Xiao B, Jha HC, Lu J, Banerjee S, Robertson ES. Kaposi's sarcoma-associated herpesvirus- 
encoded LANA can induce chromosomal instability through targeted degradation of the mitotic checkpoint kinase Bub1. J Virol. 2014;88(13):7367-78.

40. Nicolas A, Alazard-Dany N, Biollay C, Arata L, Jolinon N, Kuhn L, Ferro M, Weller SK, Epstein AL, Salvetti A, Greco A. Identification of rep-associated factors in herpes simplex virus type 1-induced adeno-associated virus type 2 replication compartments. J Virol. 2010;84(17):8871-87.

41. Waterworth DM, Li L, Scott R, Warren L, Gillson C, Aponte J, Sarov-Blat L, Sprecher D, Dupuis J, Reiner A, Psaty BM, Tracy RP, Lin H, McPherson R, Chissoe $S$, Wareham N, Ehm MG. A low-frequency variant in MAPK14 provides mechanistic evidence of a link with myeloperoxidase: a prognostic cardiovascular risk marker. J Am Heart Assoc. 2014;3(4). pii: e001074.

42. Semenza GL. Hypoxia-inducible factor 1 and cardiovascular disease. Annu Rev Physiol. 2014;76: $39-56$.

43. Dai TY, Cao L, Yang ZC, Li YS, Tan L, Ran XZ, Shi $C M$. P68 RNA helicase as a molecular target for cancer therapy. J Exp Clin Cancer Res. 2014;33:64.

\section{Мас-спектрометричний та біоінформаційний аналіз інтерактома еEF1B $\gamma$ в цитоплазматичній фракції клітин А549}

Л. М. Капустян, І. Л. Лисецький, Т. В. Бондарчук, О. В. Новосильна, Б. С. Негруцький

Мета. Виявити білкові мережі, до яких може входити фактор елонгації трансляції еЕF1B номи легені. Методи. Білки-партнери еEF1B $\gamma$ у цитоплазматичній фракції клітин аденокарциноми легені людини А549 були ідентифіковані за допомогою коіммунопреципітації із наступною рідинною хроматографією та тандемною мас-спектрометрією (LC-MS/ MS). Білкові мережі, до яких входить eEF1B $\gamma$, визначали за допомогою програми Cytoscape 3.2.0 із плагіном MCODE. Результати. Ідентифіковано 222 білкипартнери eEF1B $\gamma$ в цитоплазматичній фракції клітин A549. Функціональні мережі, які можуть формуватися цими білками, були визначені біоінформатично. Висновки. На основі експериментальних даних ви- найдено п'ять білкових мереж, у яких може брати участь eEF1B $\gamma$ в клітинах аденокарциноми легені людини. Показано, що крім трансляційних компонентів, ці мережі формуються білками, задіяними у регуляції клітинного циклу, ремоделюванні нуклеосом, транскрипції, сплайсингу і процесінгу мРНК та клітинної відповіді на оксидативний стрес.

К л юч о в і с л о в а: eEF1B $\gamma$, білок-білкові взаємодії, клітини А549.

\section{Мас-спектрометрический и биоинформационный анализ интерактома eEF1B $\gamma$ в цитоплазматической фракции клеток А549}

Л. М. Капустян, И. Л. Лисецкий, Т. В. Бондарчук, А. В. Новосильная, Б. С. Негруцкий

Цель. Выявить белковые сети, членом которых может быть фактор элонгации трансляции еEF1B $\gamma$ в клетках карциномы легкого. Методы. С помощью ко-иммунопреципитации с последующей жидкостной хроматографией и тандемной масс-спектрометрией были идентифицированы белки-партнеры еEF1B в в цитоплазматической фракции клеток аденокарциномы легкого людини А549. Белковые сети, в состав которых входит eEF1B $\gamma$, определяли с помощью программы Cytoscape 3.2.0 с плагином MCODE. Результаты. Идентифицированы 222 белка-партнера $\mathrm{eEF} 1 \mathrm{~B} \gamma$ в цитоплазматической фракции клеток А549. Функциональные сети, которые могут формироваться этими белками, были определены биоинформатически. Выводы. На основании экспериментальных данных найдено пять белкових сетей, в которых может участвовать еEF1B $\gamma$ в клетках аденокарциномы легкого человека. Показано, что кроме трансляционных компонентов, эти сети формируются белками, задействованными в регуляции клеточного цикла, ремоделировании нуклеосом, транскрипции, сплайсинга и процессинга мРНК и клеточного ответа на оксидативный стресс.

Кл юч е в ы е сл о в а: eEF1B $\gamma$, белок-белковые взаємодействия, клетки А549. 